\title{
Comparison of cardiorespiratory resistance in different menstrual cycle phases in female futsal players
}

\section{Comparación de la resistencia cardiorespiratoria en diferentes fases del ciclo menstrual en jugadoras de futsal}

\author{
Joana Nabo ${ }^{a}$, Ana Conceição ${ }^{b, c, *}$, Jose A. Parraca ${ }^{a, d}$, Pablo Tomas-Carus ${ }^{a, d}$, \\ Nuno Batalha ${ }^{\text {a,d }}$ \\ a Departamento de Desporto e Saúde Escola de Ciências e Tecnologia, Universidade de Évora, Évora, Portugal
b Sport Sciences School of Rio Maior, Rio Maior, Portugal
c Research Centre of Sports, Health and Human Development, CIDESD, STRONG Research Community, Portugal
d Comprehensive Health Research Centre (CHRC), University of Évora, Portugal
}

Received 9 September 2020; accepted 15 October 2020

\section{KEYWORDS \\ $\mathrm{VO}_{2}$ max; \\ Physical exercise; \\ Female hormones; \\ Intermittent sport}

\footnotetext{
* Corresponding author.

E-mail address: anaconceicao@esdrm.ipsantarem.pt (A. Conceição).
}

\begin{abstract}
Introduction: This study was aimed to investigated and compare the cardiorespiratory resistance of futsal players during the follicular and luteal phases of the menstrual cycle.

Material and methods: Fourteen female players (age: $24.1 \pm 4.1$ years; body mass: $59.6 \pm 9.1 \mathrm{~kg}$; height: $1.64 \pm 0.06 \mathrm{~m}$; index body mass: $22.1 \pm 2.8 \mathrm{~kg} / \mathrm{m}^{2}$ ) were submitted to a cardiorespiratory resistance test, that was performed in a calibrated treadmill, where we had as reference for the calculation of $\mathrm{VO}_{2}$ max. Each subject also performed two evaluations of the intended test, corresponding to the phases of the menstrual cycle: folicular phase (day $8 \pm 3$ ) and luteal phase (day $20 \pm 2$ ).

Results: The results of the present research showed that there were significant changes, showing higher values of the cardiorespiratory resistance in luteal phase $\left(\mathrm{VO}_{2} \max =41.199 \mathrm{ml} / \mathrm{kg} / \mathrm{min}\right)$ compared to folicular phase of the menstrual cycle $\left(\mathrm{VO}_{2} \max =39.030 \mathrm{ml} / \mathrm{kg} / \mathrm{min}\right)$, where $p=0.043$. There is still a great deal of controversy in the existing literature when considering a relationship of menstrual cycle phases to physical exercise.

Conclusion: The cardiorespiratory resistance of futsal players was increased in luteal phase compared to follicular phase, and management of the training is advisable, namely in type and volume.
\end{abstract}




\section{Introduction}

Over time, women have embarked on the world of competition in various sports. ${ }^{1-3}$ As women are increasingly involved in physical activity, from light regular exercise to highly competitive performance, more intense and strenuous training and methods are required. ${ }^{4}$ Thus, it is documented that the female reproductive system is highly sensitive to changes in relation to intrinsic and extrinsic factors, with large hormonal fluctuations and, therefore, it is extremely important

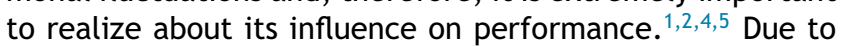
the short and cautious reproductive age in women, there is a greater vulnerability to physical changes during the different phases of the menstrual cycle. ${ }^{6}$ Fluctuations in some of the physiological parameters of the various systems may be related to fluctuations in hormone levels in the cycle phases, which may affect sports performance. 1,3,5,7-9

Menstrual cycle (MC) is an important biological event in women where several hormones interact, being responsible for changes, both reproductive and physical. The follicular phase, which is the proliferative phase, is characterized by having a duration of about nine days and there is an increase in endometrium thickness and in water content. ${ }^{10}$ The luteal phase, which is the secretory phase, begins after ovulation and lasts about thirteen days. At the end of these days a new MC begins, which is when the formation, action and growth of the yellow body takes place. ${ }^{10}$ Following the expulsion of follicular cells, hormones (progesterone and estrogen) are produced from the corpus luteum and later the endometrium enters the progestational or secretory phase where, through hormonal actions, a nutritive site is created for the fertilized egg safely implant itself in case of fertilization. ${ }^{11}$

The effect of exercise on hormone concentrations and the regulation of $M C$ may be fundamental to the understanding of sports physiology. ${ }^{12}$ Significant effects on exercise response and athletic performance were showed by hormonal variations especially in estrogen and progesterone. $^{7,13-15}$

In addition to reproductive function, female sex hormones are best known to affect numerous cardiovascular, respiratory, thermoregulatory, and metabolic parameters, and may affect performance throughout the phases of MC. 5,8,16 In the study carried out, the parameter investigated is the change, all the MC long, of the cardiorespiratory resistance in futsal players. Cardiorespiratory resistance is the ability to perform from moderate to high intensity dynamic exercises involving large muscle groups for long periods of time and it is measured by the maximum oxygen uptake $\left(\mathrm{VO}_{2}\right.$ max $)$, which refers to the maximum amount of oxygen that can be captured (by the respiratory system), fixed (in the pulmonary alveoli), transported (through the circulatory system) and used (by the muscles) by our body in a maximal effort of general characteristics. ${ }^{17} \mathrm{VO}_{2} \mathrm{max}$ has several factors that can be affected by estrogen and progesterone fluctuations during MC. ${ }^{5,7}$ The three main physiological factors involved are fuel availability, circulation and respiration. ${ }^{7}$

Most studies have reported no changes over the menstrual cycle in oxygen uptake $\left(\mathrm{VO}_{2}{ }^{\circ}\right)$, ventilation (VE), and heart rate (HR) during maximal or submaximal exercise. ${ }^{14,18,19}$ However, other studies have found higher
$\mathrm{VO}_{2}{ }^{\bullet}, \mathrm{HR}$, or VE during the luteal phase indicating a higher cardiorespiratory strain. ${ }^{7,15,20,21}$

In the present research the approached sport is futsal, characterized as a sport of intermit-tent efforts, with changes in intensity over the course of the game, predominating high intensity efforts in short intervals, with constant changes of direction, sudden accelerations and various displacements. ${ }^{22}$ Futsal, being a complex and highly demanding sport, is a sport of great research interest, particularly in the physiological domain. In addition to the type of sport and all modifiable factors, it is important to take into account the conditions under which physical activity is performed (at high altitude, in high temperature, among others), as it may cause physiological changes (not only with the $M C)$.

Therefore, is still a controversy and conflict findings in the current research regarding the changes over the menstrual cycle in cardiorespiratory variables during exercise. Thus, the purpose of this study was to verify the influence of the different phases of menstrual cycle, in futsal players, on cardiorespiratory resistance.

\section{Material and methods}

\section{Participants}

A voluntary sample of 14 players was analyzed, coming from the 1st national futsal league, (age: $24.1 \pm 4.1$ years; body mass: $59.6 \pm 9.1 \mathrm{~kg}$; height: $1.64 \pm 0.06 \mathrm{~m}$; index body mass: $22.1 \pm 2.8 \mathrm{~kg} / \mathrm{m}^{2}$ ) all healthy. As an inclusion criterion, the players should have a regular MC (twenty-eight to forty days). The exclusion criterion was to use contraceptive drugs (pills or other hormonal contraceptive means) or to present injuries with deprivation of maximum force production.

Each participant was informed of the test and possible risks and signed an informed con-sent obtained prior to the study, following the principles of the Helsinki Declaration. This investigation was approved by the University of Évora Ethics Committee ( $n^{\circ}$ 9732) and complied with current ethical regulations for a research. ${ }^{23}$

\section{Test protocol}

Height $(\mathrm{cm})$, body mass $(\mathrm{kg})$ and index body $\max \left(\mathrm{kg} / \mathrm{m}^{2}\right)$ were measured prior to performing the test. Participants attended to the laboratory after $3 \mathrm{~h}$ eating a meal, and before the test and were instructed to abstain from alcohol, caffeine, and exercise for $24 \mathrm{~h}$ before the test.

The cardiorespiratory resistance test was performed in a calibrated treadmill (Technogym Run Race 1200HC), where we had as reference for the calculation of $\mathrm{VO}_{2}$ max ${ }^{24}$ by $\mathrm{VO}_{2} \max ($ Women $): \mathrm{VO}_{2} \mathrm{max}(\mathrm{ml} / \mathrm{kg} / \mathrm{min})=1.38$ ( $\mathrm{T}$-Time in minutes) +5.22 , which is considered the indicator of cardiorespiratory resistance and essential in the assessment of the physical condition of individuals. The maximal test imply that the subject achieves volitional fatigue, which may require the presence of a physician and of an emergency equipment. The Heart Rate (HR) was continuously measured and recorded using an electronic HR monitor (Polar, Inc.). 
The participants began the test with a 5 min warm-up at $60 \%$ of maximal aerobic speed, followed by a maximum test. The maximal test protocol consisted in running in treadmill and started at a velocity of 3 miles $/ \mathrm{h}=4.5 \mathrm{~km} / \mathrm{h}$, with $0 \%$ inclination, with increases of $2.5 \%$ every $3 \mathrm{~min}$. The test ends when Heart Rate max or fatigue is reached.

In the collection and treatment of data the evaluations of the futsal players were performed in two phases of their MC: (i) folicular phase (day $8 \pm 3$ ) and 1 during the luteal phase (LP) (day $20 \pm 2$ ) of the menstrual cycle. ${ }^{25}$

Individually, we resorted to an application called "WomanLog Calendar"' (2019@womanlog.com, (P) Active App) whose purpose was, through the first day of menstruation, to more accurately differentiate the phases of the $M C$ (follicular and luteal), to identify the day of ovulation and what the fertile period of each player is. ${ }^{26}$

\section{Statistical analysis}

In the statistical analysis, the software used was IBM SPSS Statistics, version 24. To com-pare the normality of the data, the Shapiro-Wilk test was performed. Considering the variables analyzed, parametric and nonparametric tests were performed, based on variables with and without normal distribution, respecting a significance of $p<0.05$. In assessing the degree of reliability between the two tests in the follicular phase and the luteal phase, we used the intraclass correlation coefficient, with $95 \%$ confidence intervals in both repetitions.

Absolute reliability was assessed by calculating the standard error of measurement and the smallest real difference. A $T$-test was also performed for paired samples, as a function of the mean and standard deviation of the pairs and finally, the effect size was calculated. Cohen's $d$-statistic is calculated by determining the difference between two average values $(m)$ and dividing it by the population standard deviation (SD): Effect Size $=(m 1-m 2) / S D$. For Cohen's method, an effect size of $0.2-0.4$ is considered a "small" effect; 0.5-0.7 is considered a "medium" effect; and greater than or equal to 0.8 is considered a "large" effect. ${ }^{27}$ For the nonparametric statistical analysis, the Mann-Whitney $U$ test was used.

\section{Results}

The results of the test performed, according to the phase of MC, are demonstrated in Table 1, where the values are presented by Mean and SD. In this evaluation, significant differences in time (minutes) and $\mathrm{VO}_{2} \max (\mathrm{ml} / \mathrm{kg} / \mathrm{min})$ were observed along the $M C$ and the reliability of the method used was verified through the ICC values. The results obtained from $\mathrm{VO}_{2}$ max showed a good level of confidence, although it was found that the players had a higher value in luteal phase $\left(\mathrm{VO}_{2} \max =41.2199 \mathrm{ml} / \mathrm{kg} / \mathrm{min}\right)$ than follicular phase $\left(\mathrm{VO}_{2} \mathrm{max}=39.030 \mathrm{ml} / \mathrm{kg} / \mathrm{min}\right)$ (Table 1$)$.

\section{Discussion}

The aim of this study was to evaluate if the different phases of MC (folicular and luteal phases) have an influence in cardiorespiratory resistance $\left(\mathrm{VO}_{2} \max \right)$ in futsal players. The results of the present research showed that there were significant changes, showing higher values in luteal phase $\left(\mathrm{VO}_{2} \max =41.199 \mathrm{ml} / \mathrm{kg} / \mathrm{min}\right)$ compared to folicular phase. $\left(\mathrm{VO}_{2} \mathrm{max}=39.030 \mathrm{ml} / \mathrm{kg} / \mathrm{min}\right)$, where $p=0.043$.

Through the use of a progressive and continuous treadmill running test, the results obtained indicated that the maximum resistance capacity was reduced in luteal phase, $, 28,29$ contrary to the values achieved in our study. In another study, with rowing women, classified according to their level of training and competitive level, an incremental test to exhaustion was performed, using a rowing ergometer, during the follicular phase and luteal phase of the MC, where the $\mathrm{HR}$ and the $\mathrm{VO}_{2} \max ^{25}$ were evaluated. The results obtained also showed no significant differences between the two phases of $M C$ and, therefore, the resistance exercise for this sport is not influenced by the normal MC phases. ${ }^{25}$ Inversely, it has been shown in previous research that exercise time to exhaustion is improved during luteal phase, ${ }^{30}$ as reported in the study (Table 1). Consideration should be given to the type of sport practiced to validly assess whether and how the phase of MC can affect athletes' performance. For example, in soccer (which is also an intermittent sport), there is a special challenge to assess physical performance due to the current difficulty in establishing valid and reliable tests for this sport, unlike other endurance sports. In this approach, as previously mentioned, it is indicated that there is a reduction in the maximum resistance performance during luteal phase. ${ }^{8}$ In previous other studies, the aerobic performance as measured by $\mathrm{VO}_{2} \max$ does not appear to be significantly altered during a regular ovulatory MC. ${ }^{5,7}$ These results do not corroborate the measurements obtained in the study, since the values achieved indicate that $\mathrm{VO}_{2} \mathrm{max}$ is significantly improved in luteal phase.

In MC, folicular phase is characterized by low concentrations of female hormones, thus developing ovarian follicle and luteal phase is characterized by high concentrations of estrogen and progesterone. ${ }^{4}$ Estrogen promotes the proliferation and growth of specific body cells responsible for the development of most female sexual characteristics. Regarding the referenced modality, futsal, the specific motor actions of the game are: varied displacements, sudden stops, accelerations, decelerations, fast exits and changes of direction at high speed, evidencing the great demand on the power capacity, especially of fast strength and endurance. Muscle endurance, lower limb strength/power, agility, speed and flexibility are the physical abilities considered essential for this practice. ${ }^{22}$ Thus, as it is an intermittent, complex and physically demanding sport, it becomes clear the importance of focusing on the physiological level and the changes that may occur, in this case, during the players' MC. Consideration should be given to all parameters evaluated in this research, as excellent physical preparation is required to achieve the best possible performance.

Some research into female steroid hormone fluctuations has shown that both estrogen and progesterone can cause many physiological effects, including changes in the thermoregulatory, respiratory and renal system. These estrogen and progesterone side effects and their inter-action can in turn influence exercise performance. Estrogen may increase 
Table 1 Cardiorespiratory resistance results of futsal players $(n=14)$ in follicular and luteal phases of menstrual cycle using the Balke Maximal test on the treadmill.

\begin{tabular}{|c|c|c|c|c|c|c|c|c|c|}
\hline & $\begin{array}{l}\text { FP } \\
\text { Mean (SD) }\end{array}$ & $\begin{array}{l}\text { LP } \\
\text { Mean (SD) }\end{array}$ & $p$ & ICC (95\% CI) & ES & SEM & \%SEM & SRD & $\%$ SRD \\
\hline$T(\min )$ & $24.5(3.5)$ & $26.1(3.3)$ & $0.04^{*}$ & $0.7(0.3$ a 0.9$)$ & -0.5 & 1.9 & 7.3 & 5.1 & 20.3 \\
\hline HR (bpm) & $183.1(9.8)$ & $184.0(8.1)$ & 0.6 & $0.8(0.4$ a 0.9$)$ & -0.1 & 4.3 & 2.3 & 11.8 & 6.4 \\
\hline $\mathrm{VO}_{2} \max (\mathrm{ml} / \mathrm{kg} / \mathrm{min})$ & $39.0(4.8)$ & $41.2(4.6)$ & $0.04^{*}$ & $0.7(0.3$ a 0.9$)$ & -0.5 & 2.6 & 6.4 & 7.1 & 17.7 \\
\hline
\end{tabular}

$n$, sample; $m$, mean; SD, standard deviation; FP, follicular phase; LP, luteal phase; ICC, intraclass correlation coefficient; $\mathrm{Cl}$, confidence interval; ES-effect size; SEM, standard error of the mean; \%SEM, standard error of the mean (\%); SRD, smallest real difference; \%SRD, smallest real difference (\%); $T$, time; $\mathrm{HR}$, heart rate; $\mathrm{VO}_{2}$ max, maximum oxygen consumption.

$$
\text { " } p \leq 0.05 \text {. }
$$

endothelium-dependent vasodilation, ${ }^{31}$ and may also alter cardiac excitability, possibly caused by calcium antagonism or inhibition of angio-tensin-converting enzyme. Estrogen administration promotes vasodilation, reduces peripheral resistance, and increases cardiac output and heart rate. ${ }^{32,33}$ In addition, this hormone has a beneficial effect on the cardiovascular system, lowers cholesterol, and has a direct action on blood vessels, which cause vasodilation through endothelial nitric oxide synthase. ${ }^{34}$ Estrogens play a protective role against hypertension by inhibiting sympathetic nerve activity. ${ }^{35}$ In contrast, progesterone favors vasoconstriction and decreases estrogen receptor synthesis ${ }^{36,37}$ and, by direct effect on the vascular bed, promotes vasoconstrictor synthesis. ${ }^{36}$ This hormone may increase cardiac excitability, having opposite effects to estrogen. Through progesterone, there is an increase in cardiovascular pressure (a higher heart rate), at the same level of work, during follicular and luteal phases. ${ }^{38}$ Progesterone receptors have also been located in the myocardium and therefore may have an effect on cardiac contractility. ${ }^{39}$ This hormone leads to activation of the renin-angiotensin-aldosterone system, thereby increasing aldosterone production during the secretory phase. ${ }^{40}$

Still, most research suggests that $M C$ does not significantly affect $\mathrm{VO}_{2}$ max. ${ }^{1,5,7,21,26,41-44}$ Aerobic performance and cardiorespiratory adaptations during exercise were not influenced by the phases of the MC, which was not observed in our results, since $\mathrm{VO}_{2}$ max was significantly improved in luteal phase compared to folicular phase. Performance in high intensity exercise is best in luteal phase when progesterone and estradiol levels are high. ${ }^{19}$ One of the most important actions of estrogen during luteal phase is its effect on the cardiovascular system, as it may benefit long-term, submaximal exercise by increasing synthesis of glycogen and intramuscular and hepatic lipids. ${ }^{45}$ These effects occur due to increased lipolysis and increased use of free fatty acids, sparing muscle glycogen both at rest and during exercise. ${ }^{5}$

In our study, the results obtained from $\mathrm{VO}_{2}$ max may be related to fluctuations in the concentration of estrogen and progesterone, mainly in the luteal phase, where progesterone assumes a relevant role with respect to estrogen, they may have positively influenced the performance of futsal athletes. According to all studies analyzed and the results presented in this study, it can be reported that the hormonal approach is extremely important to understand what happens physiologically and physically in female athletes. The well-trained female players who practice futsal should demonstrate great physical ability, especially in terms of strength (rapid and explosive) and aerobic endurance. As a high-intensity sport, performance is likely to be better in luteal phase when hormone levels are high, and is corroborated by an earlier study. ${ }^{19}$

The cardiorespiratory resistance of futsal players was increased in luteal phase compared to follicular phase, and management of the training is advisable, namely in type and volume. Further research is needed with an increase in sample size and also hormonal monitoring in the different phases of MC. It would be also interesting to evaluate more than one $M C$ and have a control group of sedentary women in the same age group.

\section{Funding}

This study benefited from the support of the UÉvora UniverCIDADE IV program. Portuguese Institute for Sport and Youth - I.P., Support for Sport Activity 2018, Sport Development Program Agreement, CP/605/DD/2018; and by national funding through the Portuguese Foundation for Science and Technology, I.P., under project UID04045/2020.

\section{Conflict of interest}

No potential conflict of interest was reported by the authors.

\section{Acknowledgements}

The authors express special thanks to the athletes and coaches for their cooperation throughout the study.

\section{References}

1. Lebrun C, McKenzie D, Prior J, Taunton J. Effects of Menstrual cycle on athletic performance. Med Sci Sports Exerc. 1995:437-44.

2. Pinto I, Teixeira A, Sales R. Perfil do ciclo menstrual da elite no futebol: uma relação de composição corporal sugerida. Rev Bras Futsal Futeb. 2011;3:72-4.

3. Teixeira A, Júnior W, Moraes E, Alves H, Dias M. Efeitos das diferentes fases do ciclo menstrual na composição corporal de universitárias. Rev Bras Presc Fisio Exerc. 2012;6:428-32.

4. Roupas ND, Georgopoulos NA. Menstrual function in sports. Hormones. 2011;10:104-16, http://dx.doi.org/10.14310/horm.2002.1300. 
5. Frankovich RJ, Lebrun CM. Menstrual cycle, contraception, and performance. Athletic Woman. 2000;19:251-71, http://dx.doi.org/10.1016/S0278-5919(05)70202-7.

6. Pallavi LC, Souza UJ, Shivaprakash G. Assessment of musculoskeletal strength and levels of fatigue during different phases of menstrual cycle in young adults. J Clin Diagn Res. 2017;11:CC11-3, http://dx.doi.org/10.7860/JCDR/2017/24316.9408.

7. Janse de Jonge XAK. Effects of the menstrual cycle on exercise performance. Sports Med. 2003;33:833-51, http://dx.doi.org/10.2165/00007256-200333110-00004.

8. Julian R, Hecksteden A, Fullagar H, Meyer T. The effects of menstrual cycle phase on physical performance in female soccer players. PLOS ONE. 2017;12:e0173951, http://dx.doi.org/10.1371/journal. pone.0173951.

9. Nicolay CW, Kenney JL, Lucki NC. Grip strength and endurance throughout the menstrual cycle in emenorrheic and women using oral contraceptives. Int J Ind Ergon. 2007;37:291-301, http://dx.doi.org/10.1016/j.ergon.2006.11.004.

10. Moore KL, Persaud TVN. Embriología Clínica. 6a ed. México: Interamericana Mc Graw-Hill; 1999.

11. Wells C. Mujeres, Deporte y Rendimiento (perspectiva fisiológica), vol. 2. Barcelona: Editorial Paidotribo; 1992.

12. Wojtys E, Jannausch M, Kreinbrink J, Harlow S, Sowers $M$. Athletic activity and hormone concentrations in high school female athletes. J Athl Train. 2015;50:185-92, http://dx.doi.org/10.4085/1062-6050-49.3.62.

13. Hackney AC. Sex hormones, exercise and women. Scientific and clinical aspects. Cham, Switzerland: Springer; 2017.

14. Pivarnik JM, Marichal CJ, Spillman T, Morrow JR Jr. Menstrual cycle phase affects temperature regulation during endurance exercise. J Appl Physiol. 1992;72:543-8, http://dx.doi.org/10.1152/jappl.1992.72.2.543.

15. Williams TJ, Krahenbuhl GS. Menstrual cycle phase and running economy. Med Sci Sports Exerc. 1997;29:1609-18, http://dx.doi.org/10.1097/00005768-199712000-00010.

16. Barba- Moreno L, Cupeiro R, Romero-Parra N, de Jonge XAKJ, Peinado AB. Cardiorespiratory responses to endurance exercise over the menstrual cycle and with oral contraceptive use. J Strength Cond Res. 2019, http://dx.doi.org/10.1519/JSC.0000000000003447.

17. Ruivo R. Novo Manual de Avaliação e prescrição de Exercício. $1 \underline{a}$ ed. Carcave-los: SELF; 2018.

18. Bailey SP, Zacher CM, Mittleman KD. Effect of menstrual cycle phase on carbohydrate supplementation during prolonged exercise to fatigue. J Appl Physiol. 2000;88:690-7, http://dx.doi.org/10.1152/jappl.2000.88.2.690.

19. Jurkowski JE, Jones NL, Toews CJ, Sutton JR. Effects of menstrual cycle on blood lactate, $\mathrm{O}_{2}$ delivery, and performance during exercise. J Appl Physiol Respir Environ Exerc Physiol. 1981;51:1493-9, http://dx.doi.org/10.1152/jappl.1981.51.6.1493.

20. Hessemer V, Brück K. Influence of menstrual cycle on thermoregulatory, metabolic, and heart rate responses to exercise at night. J Appl Physiol. 1985;59:1911-7, http://dx.doi.org/10.1152/jappl.1985.59.6.1911.

21. Schoene RB, Robertson HT, Pierson DJ, Peterson AP. Respiratory drives and exercise in menstrual cycles of athletic and nonathletic women. J Appl Physiol Respir Environ Exerc Physiol. 1981;50:1300-5, http://dx.doi.org/10.1152/jappl.1981.50.6.1300.

22. Oliveira E, Pacheco V, Navarro F, Navarro A. Comportamento da glicemia em jogadores profissionais durante uma partida de futsal pela Liga Nacional. Rev Bras Presc Fisio Exerc. 2008;2:90-6.

23. Harriss DJ, Macsween A, Atkinson G. Standards for ethics in sport and exercise science research. Int J Sports Med. 2017;38:1126-31, http://dx.doi.org/10.1055/s-0043-12400.
24. Glass S, Gregory B. ACSM's metabolic calculations handbook. Baltimore: Lippincott Williams \& Wilkins; 2007. p. 25-74.

25. Vaiksaar S, Jürimäe $J$, Mäestu J, Purge $P$, Kalytka $S$, Shakhlina L, et al. No effect of menstrual cycle phase and oral contraceptive use on endurance performance in rowers. J Strength Cond Res. 2011;25:1571-8, http://dx.doi.org/10.1519/JSC.0b013e3181df7fd2.

26. Constatini NW, Dubnov G, Lebrun CM. The menstrual cycle and sport performance. Clin Sports Med. 2005;24:E51-82, http://dx.doi.org/10.1016/j.csm.2005.01.003.

27. Cohen J. The $t$ test for means. In: Statistical power analysis for the behavioral sciences. 2a ed. New York: Lawrence Erlbaum Associates; 1988. p. 19-66.

28. Campbell SE, Angus DJ, Febbraio MA. Glucose kinetics and exercise performance during phases of the menstrual cycle: effect of glucose ingestion. Am J Physiol Endocrinol Metab. 2001;281:E817-25, http://dx.doi.org/10.1152/ajpendo.2001.281.4.E817.

29. Lebrun CM. Effect of the different phases of the menstrual cycle and oral con-traceptives on athletic performance. Sports Med. 1993;16:400-30, http://dx.doi.org/10.2165/00007256-199316060-00005.

30. Fernández A, Muñiz Y, Llerena M. Ciclo menstrual y rendimiento físico en es-tudiantes de Secundaria Básica. Portal deportivo La Revista, Deporte, Ciencia y Actividad Física; 2010. Ano 3, № 18.

31. Chan NN, MacAllister RJ, Colhoun HM, Vallance $P$, Hingorani AD. Changes in endothelium-dependent vasodilatation and alpha-adrenergic responses in resistance vessels during the menstrual cycle in healthy women. J Clin Endocrinol Metab. 2001;86:2499-504, http://dx.doi.org/10.1210/jcem.86.6.7581.

32. Tostes RC, Nigro D, Fortes ZB, Carvalho MH. Effects of estrogen on the vascular system. Braz J Med Biol Res. 2003;36:1143-58, http://dx.doi.org/10.1590/S0100-879X2003000900002.

33. Zhu Y, Bian Z, Lu P. Abnormal vascular function and hypertension in mice de-ficient in estrogen receptor beta. Science. 2002;295:505-8, http://dx.doi.org/10.1126/science.1065250.

34. Miller VM, Duckles SP. Vascular actions of estrogens: functional implications. Pharmacol Rev. 2008;60:210-41, http://dx.doi.org/10.1124/pr.107.08002.

35. Kotchen JM, Kotchen TA. Impact of female hormones on blood pressure: review of potential mechanisms and clinical studies. Curr Hypertens Rep. 2003;5:505-12, http://dx.doi.org/10.1007/s11906-003-0059-0.

36. Graham J, Clarke C. Physiological action of progesterone in target tissues. Endocr Ver. 1997;18:502-19, http://dx.doi.org/10.1210/edrv.18.4.0308.

37. White MM, Zamudio S, Stevens T, Tyler R, Lindenfeld J, Leslie $\mathrm{K}$, et al. Estrogen, progesterone, and vascular reactivity: potential cellular mechanisms. Endocr Rev. 1995;16:739-51, http://dx.doi.org/10.1210/edrv-16-6-739.

38. Birch KM, Reilly T. Manual handling performance: the effects of menstrual cycle phase. Ergonomics. 1999;42:1317-32, http://dx.doi.org/10.1080/001401399184974.

39. Barbagallo M, Licata L, Shan J, Bing L, Karpinski E, Pang P, et al. Vascular effects of progesterone: role of cellular calcium regulation. Hypertension. 2001;37:142-7, http://dx.doi.org/10.1161/01.hyp.37.1.142.

40. Szmuilowicz E, Adler GK, Williams JS, Green DE, Yao TM, Hopkins PN, et al. Relationship between aldosterone and progesterone in human menstrual cycle. J Clin Endocrinol Metab. 2006;91:3981-7, http://dx.doi.org/10.1210/jc.2006-1154.

41. Allsen PE, Parsons P, Rex Bryce G. The effect of the menstrual cycle on maximum oxygen uptake. Phys Sportsmed. 1977;5:53-5, http://dx.doi.org/10.1080/00913847.1977.11710616. 
J. Nabo, A. Conceição, J.A. Parraca et al.

42. Bemben DA, Salm PC, Salm AJ. Ventilatory and blood lactate responses to maximal treadmill exercise during the menstrual cycle. J Sports Med Phys Fitness. 1995;35:257-62.

43. Dean TM, Perreault L, Mazzeo RS, Horton TJ. No effect of menstrual cycle phase on lactate threshold. J Appl Physiol. 2003;95:2537-43, http://dx.doi.org/10.1152/japplphysiol.00672.2003.
44. Lebrun CM. Effects of the menstrual cycle and oral contraceptives on athletic performance. In: Drinkwater B, editor. The encyclopedia of sports medicine, vol. VIII: Women in sport. Oxford, United Kingdom: Blackwell Science; 2000. p. 37-61.

45. Reilly T. The menstrual cycle and human performance: an overview. Biol Rhythm Res. 2000;31:29-40, http://dx.doi.org/10.1076/0929-1016(200002)31:1;1-0;FT029. 